\title{
Relationship between selected characteristics of the respondent greengram growers with extent of adoption of recommended package of practices: A study in Nagaon district of Assam
}

\author{
ARUP JYOTI GOSWAMI ${ }^{1}$, CHANDAN KR. DEKA* AND PABITRA KR. DAS ${ }^{2}$ \\ Krishi Vigyan Kendra, DHUBRI (ASSAM) INDIA
}

(Email : ckdeka@ rediffmail.com)

\begin{abstract}
The study was carried out to see the extent of adoption of recommended package of practices of greengram and its relationship with selected characteristics of the respondent greengram growers. The present study was conducted Nagaon district of Assam. The survey was conducted in the month of February to March, 2016. The study revealed that majority of the respondents (63.33\%) exhibited medium level of extent of adoption of recommended package of practices of black gram and greengram. The study revealed that in case of greengram, the cent per cent of the farmers adopted sowing time and land preparation. Recommended seed rate, manual weeding operation and FYM were adopted by 95.83 per cent, 70.83 per cent and 62.50 per cent, respectively. While in case of growing of HYV, 30.83 per cent adopted HYV of greengram. While 14.17 per cent farmers adopted chemical pest control and the adoption of fertilizer application without rhizobium, chemical disease control and spacing were 8.33, 5.83 and 4.17 per cent, respectively. Nobody was found to adopt practices like seed inoculation with Rhizobium, fertilizer application with Rhizobium, chemical weed control and protection against storage-pests. A positive and significant relationship was found between extent of adoption and size of operational land holding, urban contact, knowledge on pulse crops and annual farm income. On the other hand, age, education level, family size, area under pulse crops, sources of finance, innovation proneness and risk orientation could not establish any significant relationship with the extent of adoption of scientific cultivation of pulse crops.
\end{abstract}

Key Words : Extent of adoption, Pulse crops, Package of practice

View Point Article : Goswami, Arup Jyoti, Deka, Chandan Kr. and Das, Pabitra Kr. (2017). Relationship between selected characteristics of the respondent greengram growers with extent of adoption of recommended package of practices: A study in Nagaon district of Assam. Internat. J. agric. Sci., 13 (2) : 327-330, DOI:10.15740/HAS/IJAS/13.2/327-330.

Article History : Received : 30.01.2017; Revised : 26.04.2017; Accepted : 10.05.2017

\footnotetext{
* Author for correspondence:

${ }^{1}$ Biswanath College of Agriculture (AAU), Biswanath, CHARIALI (ASSAM) INDIA

${ }^{2}$ Department of Extension Education, Biswanath College of Agriculture (AAU), Biswanath, CHARIALI (ASSAM) INDIA
} 